\title{
First report of the genus Systelloderes (Hemiptera: Heteroptera: Enicocephalidae) in Guzmania multiflora (Bromeliaceae) in Colombia
}

\author{
Primer registro del género Systelloderes (Hemiptera: Heteroptera: Enicocephalidae) \\ en Guzmania multiflora (Bromeliaceae) en Colombia \\ FABIOLA OSPINA-BAUTISTA ${ }^{1}$, CAMILO LLANO² and EMILIO REALPE ${ }^{3}$
}

\begin{abstract}
The relationship between purely predacious Enicocephalidae and plants is relatively unknown. This study reports the occurrence of two species of Systelloderes in Guzmania multiflora (Bromeliaceae) from a mountain forest of Colombia. This was conducted in the Reserva Forestal Protectora de las Cuencas Hidrográficas de Rio Blanco y Quebrada Olivares forest reserve in Caldas, Colombia. Bromeliads located at heights between one to three meters above the ground were used to collect Enicocephalidae. Systelloderes species have been previously reported in Colombia; however, this genus had not been found in bromeliads until now.
\end{abstract}

Key words: True bugs, Neotropics, epiphytes, phytotelm.

\begin{abstract}
Resumen: Se conoce poco sobre la relación entre depredadores de la familia Enicocephalidae y plantas. Se reporta la presencia de dos especies de Systelloderes habitando en plantas de Guzmania multiflora (Bromeliaceae) en un bosque de montaña de Colombia. Este estudio se llevó a cabo en la Reserva Forestal Protectora de las Cuencas Hidrográficas de Rio Blanco y Quebrada Olivares Manizales, Caldas, Colombia, donde se recolectaron bromelias entre cero y tres metros de altura. Aunque especies de Systelloderes habían sido reportadas con anterioridad en Colombia, este género no había sido encontrado dentro de bromelias.
\end{abstract}

Palabras clave: Chinches, Neotrópico, epífitas, fitotelmata.

\section{Introduction}

The Enicocephalidae (Hemiptera: Heteroptera) is a predator family that lives either detritus above ground or other places where decomposing organic matter has accumulated (Stys 1995). Little is known about the relationship between Enicocephalidae and plants as bromeliads, except for studies in Brazil and Peru, where the family Enicocephalidae have been reported living in Vriesea inflata (Wawra) Wawra and Tillandsia spp. (Bromeliaceae) (Mestre et al. 2001; Parker et al. 2012). In Colombia, the family has been recorded only from Espeletia sp. (Asteraceae) (Wygodzinsky and Schmidt 1991). Here we report adults of two species of Systelloderes (Blanchard, 1852) (Hemiptera: Heteroptera: Enicocephalidae) inhabiting Guzmania multiflora Ruiz \& Pavón, 1802 (Bromeliaceae) from Colombia.

\section{Materials and methods}

The study was conducted in a Secondary forest of "Reserva Forestal Protectora de las Cuencas Hidrográficas de Rio Blanco y Quebrada Olivares" locates on Central Cordillera of Colombia. The mean annual precipitation is $2,500 \mathrm{~mm}$ with rainfall season between April and May and another on October. The annual temperature average is $19{ }^{\circ} \mathrm{C}$ (CORPOCALDAS 2010). Plants of Guzmania multiflora
(Bromeliaceae) located at heights between one to three meters above the ground were collected in March 2012 to survey the aquatic and terrestrial fauna inhabiting within them. The bromeliads had an average height (root base to shoot tip) of $76.22 \mathrm{~cm}$ and an average of $0.862 \mathrm{~m}^{2}$ of foliar cover. We use the taxonomic key of Wygodzinsky and Schmidt (1991) to identify Enicocephalidae specimens.

Material examined. Stystelloderes spp. 2 . COLOMBIA. Caldas, Manizales, Reserva Forestal Protectora de las Cuencas Hidrográficas de Rio Blanco y Quebrada Olivares $05^{\circ} 7^{\prime} 30.83^{\prime \prime} \mathrm{N} 75^{\circ} 26^{\prime} 48.89^{\prime \prime} \mathrm{W}$ from 2150 to $2400 \mathrm{~m}$. Apr2014. Ospina, F. [ANDES E16129, E161130].

\section{Results and discussion}

Specimens of Systelloderes were found in the terrestrial part of bromeliads (Figs. 1, 2). These were deposited at Museum of Natural History of Los Andes University. Aquatic immature of Helodidae, Psychodidae, Culicidae, and Chironomidae families and the adults of Dermaptera, Formicidae, Theridiidae, Ctenidae, Anyphaenidae, Oonopidae, Dipluridae, and Liocranidae was also observed in G. multiflora.

Systelloderes had not been found in bromeliads or the Central Cordillera of Colombia; although, it had been

\footnotetext{
${ }^{1}$ Ph. D. Researcher of Laboratorio de Zoología y Ecología Acuática-LAZOEA, Departamento de Ciencias Biológicas, Universidad de los Andes, Bogotá, D. C., Colombia. Professor of Universidad de Caldas, Manizales, Caldas, Colombia, mf.ospina35@gmail.com. ${ }^{2}$ Student Maestría en Ciencias Biológicas, Grupo en investigación Bionat: Biodiversidad y recursos naturales Universidad de Caldas, Manizales, Caldas, Colombia. ${ }^{3}$ Ph. D. Professor. Laboratorio de Zoología y Ecología Acuática-LAZOEA, Departamento de Ciencias Biológicas, Universidad de los Andes, Bogotá, D. C., Colombia. Corresponding author: Fabiola Ospina-Bautista. Ph. D. Researcher of Laboratorio de Zoología y Ecología Acuática-LAZOEA, Departamento de Ciencias Biológicas, Universidad de los Andes, Bogotá, D. C., Colombia. Professor of Universidad de Caldas, Manizales, Caldas, Colombia, mf.ospina35@gmail.com.
} 


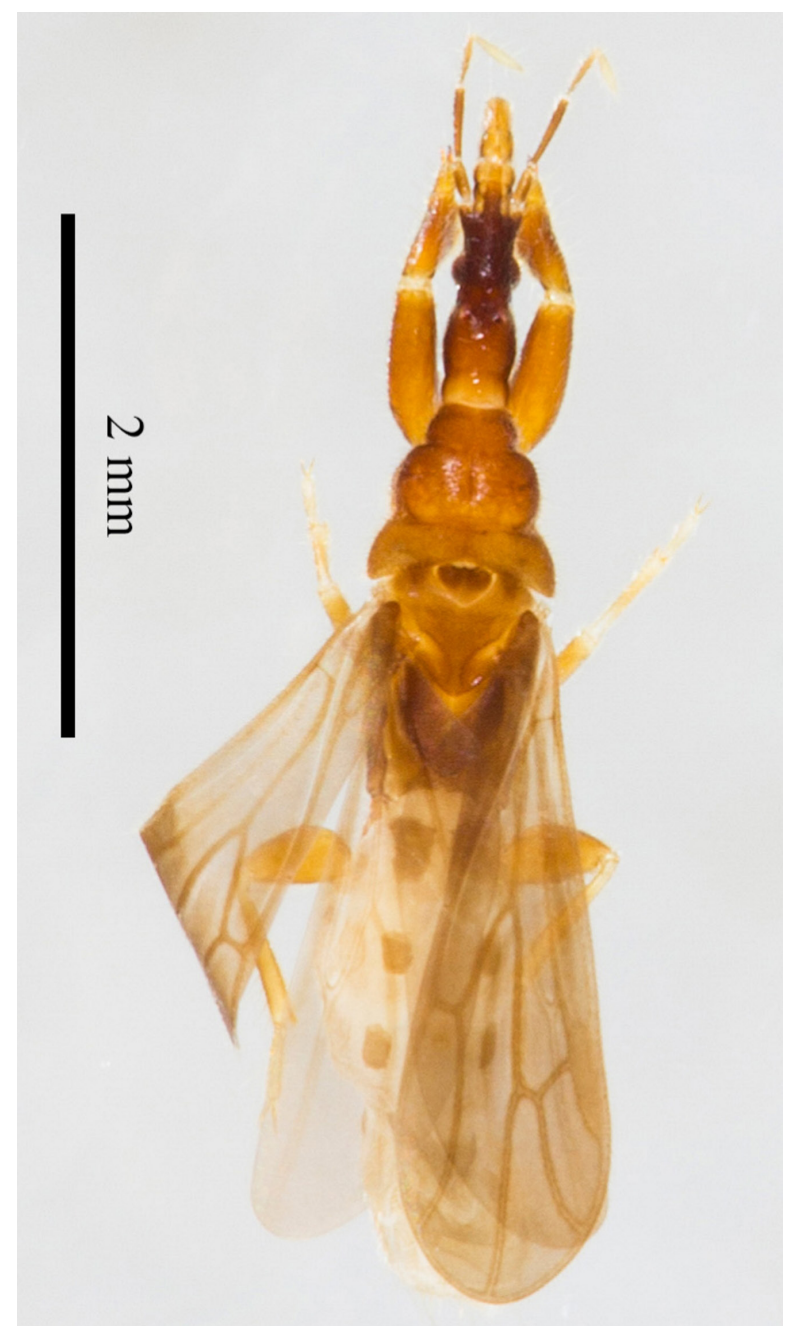

Figure 1. Enicocephalidae found into Guzmania multiflora (Bromeliacea) from mountain forest. Systelloderes sp. dorsal view. reported in Colombia (Wolda 1975; Wygodzinsky and Schmidt 1991). The bromeliads may offer damp habitat to Enicocephalidae during dry periods and provide prey in the form of adult insects ovipositing into bromeliad or immature stages that emerge from bromeliads. Future research should assess the factors that allow the presence of Enicocephalidae in bromeliads and improve the taxonomic knowledge of this family in Colombia.

\section{Acknowledgements}

We would like to thank Diane Srivastava for comments on manuscript and Yeisson Gutierrez for the images. This research was supported by funds from Convocatoria Proyectos de Investigación 2012-1, Facultad de Ciencias Universidad de los Andes. COLCIENCIAS Fellowship No. 567 supported F. Ospina-Bautista during this work.

\section{Literature cited}

CORPOCALDAS. 2010. Plan de manejo de Reserva forestal protectora de las cuencas hidrográficas de Rio Blanco y Quebrada Olivares. Corporación autónoma regional de Caldas. $145 \mathrm{p}$.

MESTRE, L. A. M.; ARANHA, J. M. R.; ESPER, M. D. L. P. 2001. Macroinvertebrate fauna associated to the bromeliad Vriesea inflata of the Atlantic Forest (Paraná State, Southern Brazil. Brazilian Archives of Biology and Technology 44 (1): 89-94.

PARKER, D.; ZAVORTINK, T.; BILLO, T.; VALDEZ, U.; EDWARDS, J. 2012. Mosquitoes and other arthropod macro fauna associated with tank bromeliads in a Peruvian cloud forest. Journal of the American Mosquito Control Association 28 (1): 45-46.

STYS, P. 1995. Enicocephalomorpha. pp. 67- 73. In: Schuh, R.; Slater, J. True bugs of the world (Hemiptera: Heteroptera): Classification and Natural History. Cornell University press. $336 \mathrm{p}$.

WOLDA, H. 1975. The Ecosystem of Malpelo, pp. 21-26. In: Graham, J. (Eds.). The biological investigation of Malpelo
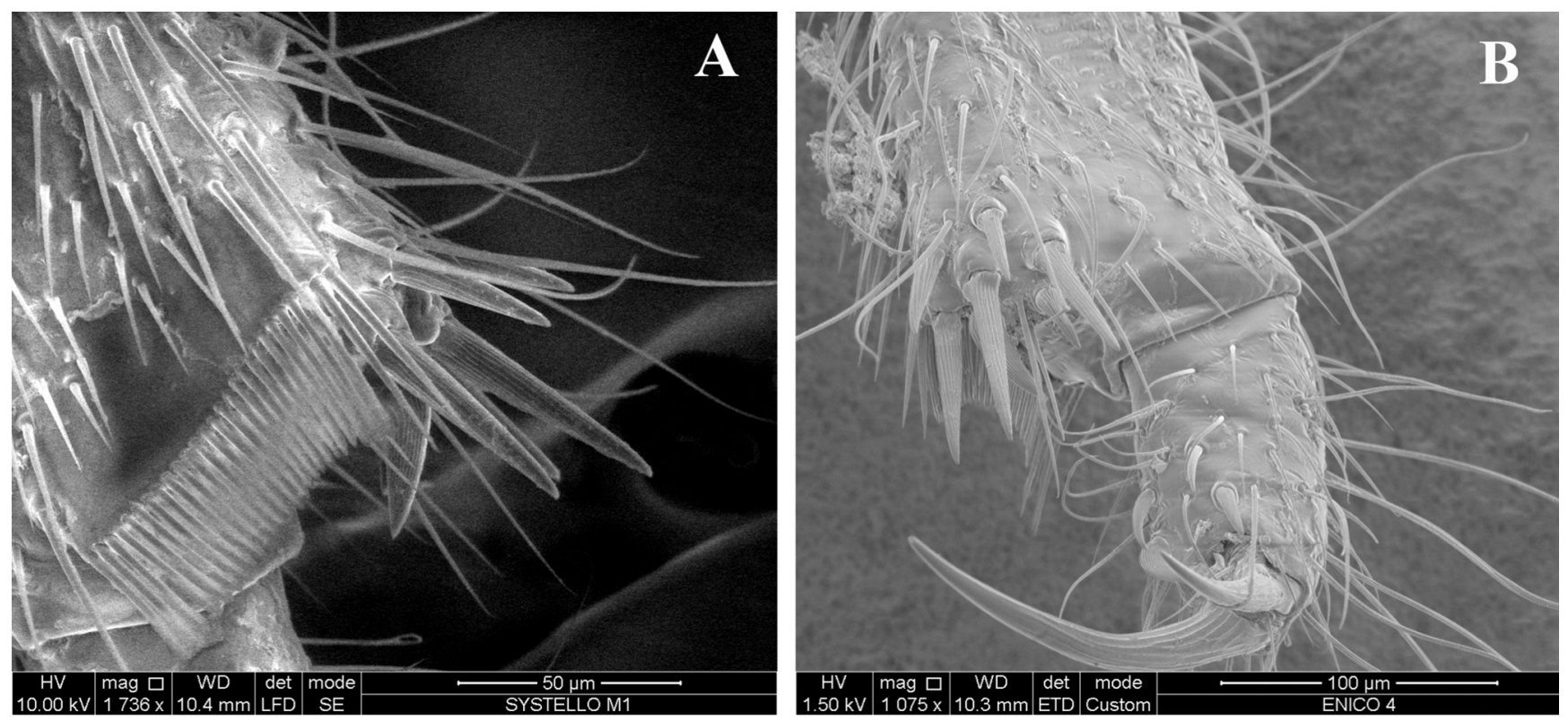

Figure 2. Systelloderes sp. SEM. A. Apicitibial comb, foreleg. B. Apicitibial armature, foreleg. State view. 
Island, Colombia. Smithsonian Contributions to Zoology Number 176 Smithsonian Institution press, Washington. 98 p.

WYGODZINSKY, P.; SCHMIDT, K. 1991. Revision of the new world Enicocephalomorpha (Heteroptera). Bulletin of the American Museum of Natural History 200. 265 p.

Received: 9-Jul-2016 • Accepted: 6-Jul-2017
Suggested citation:

OSPINA-BAUTISTA, F.; LLANO, C.; REALPE, E. 2018. First report of the genus Systelloderes (Hemiptera: Heteroptera: Enicocephalidae) in Guzmania multiflora (Bromeliaceae) in Colombia. Revista Colombiana de Entomología 44 (1): 132134. Enero - Junio 2018. 